\title{
Voluntary Repatriation to Liberia
}

\author{
Omar Abdi and Carl Tinstman
}

The Liberian civil war, which triggered the refugee crisis, began in December 1989 when the National Patriotic Front of Liberia (NPFL) led by Charles Taylor crossed the border from Côte d'Ivoire and attacked the government forces in the Nimba area, which is inhabited mostly by Gio and Mano tribes. The Liberian army of Samuel Doe's government retaliated against the civilian population of Nimba by burning and looting villages, and killing at will. The barbaric actions of the government forces encouraged more Gio and Mano civilians to join the rebel forces. The NPFL in turn attacked civilians from the president's Krahn tribe and the Mandingoes who appeared to support the Doe regime. In no time, the campaign to overthrow the Doe government became a brutal tribal-based civil war.

As the war spread to other countries, thousands of Liberians fled to the neighbouring West African countries of Guinea, Côte d'Ivoire, Sierra Leone, Ghana and Nigeria. Those refugees were welcomed by their hosts in an unprecedented way. In many villages bordering Liberia, the refugees and indigenous people are of the same ethnic group and speak the same language. Many are relatives or acquaintances. The locals took in refugees and shared their land and food with them. Although there was no need to establish refugee camps, external assistance was required. However, the international community failed to respond immediately, and it was to be many months before relief was to reach the host village communities in the neighbouring countries, most of whom were already impoverished before the refugee influx.

\section{Voluntary Repatriation}

The military and political conflict in Liberia is not yet resolved. Liberia is cur-

Omar Abdi is a UNICEF program officer and Carl Tinstman is a UNICEF representative in Liberia. rently divided into three parts. The Interim Government of National Unity (IGNU), installed by the Economic Community of West African States (ECOWAS) and protected by the Economic Community Monitoring Group (ECOMOG), controls only the capital of Monrovia. The United Liberation Movement for Democracy (ULIMO), which consists mainly of what isleft of theDoe's army, has recently captured the Bomi and Cape Mount areas from the NPFL, who rule the rest of the country. Efforts to settle the disputes are hampered by the NPFL, which rejects the ECOWASbrokered peace agreements that call for all warring factions to disarm and encamp their fighters before holding free and fair elections.

In the two years since ECOMOG installed the interim government in Monrovia, approximately 80,000 Liberian refugees have returned home to Monrovia. The number of spontaneous returnees in NPFL-held territory is not known, but is believed to be low because refugees want their security guaranteed before repatriating. Currently, the security in Liberia is precarious, particularly in areas outside of Monrovia. In early October 1992, Charles Taylor formally declared war on ECOMOG, threatened to attackMonrovia, and NPFL forces and ECOMOG forces are currently fighting on the outskirts of the capital.

\section{Alternative Approaches to Repatriation}

In addition to spontaneous return, other forms of repatriation are being considered in Liberia. However, there are some bureaucratic prerequisites before the UNHCR-assisted organized repatriation can take place. For example, a general amnesty should be given for all combatants. A triparty agreement between the UNHCR, the countries of asylum and Liberia that ensures the protection of returnees should be effected. Organized repatriation cannot take place with the current conflict and lack of a recognized government in Liberia.

As an alternative, a less bureaucratic semiorganized repatriation is being considered. Under this form of repatriation, returning refugees are given information, a transport allowance and a reintegration package at the final destination. Prospective returnees find their own way to their villages. The semiorganized repatriation provides some material assistance, but does not guarantee the protection of the returnees, which is particularly crucial in times of conflict. How can protection of returnees be assured in such cases? Issues related to the protection of returning Liberian refugees was not discussed during the series of talks between the warring factions. UNHCR and the United Nations did not participate in these talks where a cease-fire between the warring factions was negotiated by ECOWAS.

\section{Returnees and Liberia's Internal Politics}

The Liberian refugees in neighbouring countries constitute almost one-third of Liberia's total population. Thus, their vote would have a major impact on the outcome of future elections. Because most of the refugees fled from areas captured by Charles Taylor's NPFL and many of them were mistreated by the rebel forces, some politicians in Monrovia would like the election to be held after refugees are repatriated to capitalize on this fact. The Interim Government of National Unity has an active repatriation commission that advocates repatriation of refugees despite the stalemate in the political settlement. The commission vigorously pursues its objectives of returning as many refugees as possible to Monrovia before elections are held. It raises funds through soccer games and collects donations from various charities in order to facilitate the transportation of 